\title{
SOCIAL MEDIA AS A MARKETING COMMUNICATION TOOL USED BY FAMILY FIRMS
}

\author{
[Sociální média jako nástroj marketingové komunikace v rodinných firmách]
}

\author{
Otakar Ungerman ${ }^{1}$ \\ ${ }^{1}$ Technical University of Liberec, Faculty of Economics, Voroněžská 13, 46001 Liberec 1 \\ E-mail: otakar.ungerman@tul.cz
}

\begin{abstract}
This work presents a two-year project that focused on two areas of the business economy. The first part focuses on social media, a progressive tool for marketing communication that enables a company to gain a competitive advantage through better applied business marketing. The second part deals with companies that can be defined as family firms, which are mainly owned by persons related to each other. This work also presents the process that led to setting up a communication model usable for social media. The first theoretical part took a year and consisted of two primary studies in combination with qualitative and quantitative research. It was followed by a statistical evaluation with the aid of descriptive statistics, to which was linked a factor analysis. The practical resolution of the implementation of social media into a family firm corresponds to the theoretical part and was monitored for one year. The main purpose of this work is to describe in detail as well as evaluate the implementation of social media into family firms. The reason for this project was to help family firms face the competition and to help sustain traditional companies upholding certain values.
\end{abstract}

Key words: business marketing, family business, marketing communication, social media, sustainability.

JEL classification: M31

Doručeno redakci: 9.6.2015; Recenzováno: 11.6.2015; 20.6.2015; Schváleno k publikování: 23.9.2015

\section{Introduction}

This work presents a project in which experienced experts, a psychologist and academic staff participated. All of the participants in the project examined the current situation of modern marketing communication. An important role in modern marketing is played by communication, mainly with customers, suppliers and the public. All forms of communication, including messages from individuals or entire organisations, represent a communicator, influence trustworthiness and contribute to the forming of a company's image. It is important to focus on the material form of the contents of messages, the cultivation of expression and a creative means of presentation. Using social media has become a trend in marketing communication. One characteristic of this is the ability to address a large target group in as short a time as possible to convey messages to their recipients, in most cases at minimal cost. Over the relatively short period of their existence, social media have undergone irreversible development. The reason is the huge potential of social media in their use for commercial purposes.

The main aim of this work was to identify ways of utilizing social media for commercial communication with consumers. Another aim of this work was to identify options for using social media in commercial communication with consumers. Fulfilment of this aim was achieved through studying, primary research and statistical analyses, from which the specific communication is composed. Then followed implementation of the model in practice and its subsequent evaluation. The results can then serve as a guide for other companies facing competition with multinational chains. Although social media can be used by any business, this contribution focuses on their use by family firms. These firms can be characterised as 
businesses over which a family has the decisive influence. Such decisive influence is identifiable if a family entirely dominates the company in relation to one of the decisive factors, such as equity or membership in the statutory body, or if the lesser influence of one factor is made up for by the corresponding influence of another factor. However, one necessary condition is the family's share of equity.

\section{Literature Overview}

Marketing has come to the fore in the modern business world. This is reflected by the fact that in many companies marketing costs make up to $50 \%$ of all corporate costs (Kotler, 2003). Companies that maintain a long-term leading position in the market realise that marketing is a key business activity and is crucial to the success of the business. Crainer states that "marketing reveals the needs of the customer, it designs products that meet their requirements and demands, and then creates a support system designed to ensure customer satisfaction" (Crainer, 2000). For most businesses and organisations, the place where customers willingly spend time - often engaged in conversation about the business or organisation - is a social network or on-line community dedicated not to brands, products, or services, but rather to other people like themselves, with interests like their own (Markova and PetkovskaMirčevska, 2013). One of the latest trends in marketing is the use of social media, which have become an integral part of applying a marketing communication strategy (Cervenková, Simek and Stoces, 2011). Social media via the internet brings together people who cannot physically meet. Social media as a tool has various purposes and serves for sharing information and entertaining users of a virtual network, helping others find work and forming associations based on ethnicity or other categories (Homolková and Taliánová, 2012). The popularity of internet social media over the last few years has grown extremely quickly, and particularly among young people it is one of the most utilised means of communication ever, which is also confirmed by research by the organisation EUKidsOnline. Social media can be summarised in relation to marketing using the following points:

- Social media are constantly changing, and their contents are formed as well as shared by users. Marketers can quickly find out on social media what customers demand, what their opinions are regarding brands and what they complain about (Janouch, 2011, p. 210).

- Using social media can represent a competitive advantage, an aid that can make a business exceptional (Blažková and Dědková, 2014).

- There are situations when social media save time or help acquire information that a company otherwise would not get. Subsequent sharing of information among fans represents an opportunity to spread commercial messages in a vital way (Dunda, 2011).

- Social media provide feedback, create a relationship between a company and a fan, provide opportunities for applying targeted advertising, contribute to the acquisition of new customers and help boost the reputation of a brand or product (Bednár., 2011). Social media as a tool in relation to the customer needs to be seen as a tool for building a long-term relationship and as an opportunity to form the company's image in a targeted manner at relatively low cost. Activities on social media are conditioned by interaction with the target group and getting to know their views and opinions, which can then be used for the benefit of marketing communication (Fedorko and Bacík, 2013).

Interesting results related to research into social media have been presented by Fishburn Hedges and Echo, who state that year-on-year more than 18 million customers in Great Britain have communicated with brands via social media. Up to $65 \%$ of addressed customers who have used a form of communication via social media also agree with the view that social media represent a better form of communication than traditional tools (McNaughton, 2012). The results of research by the marketing agency Conversocial, published in October 2013, 
focus primarily on customer support in social media environments. The research points out that $81 \%$ of the top 100 on-line vendors respond to customer support inquiries via Twitter. About $80 \%$ of companies also communicate with customers for support purposes via Facebook (Conversocial, 2013). Social Media Today and SAP have presented results, according to which of 118 addressed companies, $71 \%$ stated that they actively used social networks as a tool for customer support. Within this group of respondents, more than $65 \%$ of companies stated that they viewed the influence of social networks on the customer support process positively or very positively (Heiligman and Lieu, 2012).

Family businesses are understood worldwide as the largest driver of the economy, since $80 \%$ of all businesses in the world are in the hands of families (such as retail chain Wal-Mart and car maker Ford). Interest in family businesses is growing worldwide, as evidenced by the increasing use of the terms "family business" or "family company" in scientific articles (Hnátek and Hnátková, 2014). However, in Central Europe, family business is understood as the activity of small or at the most mid-sized enterprises. Such situation has arisen in Central and Eastern Europe thanks to the post-war nationalisation of large family companies, whose tradition no one managed to continue after the fall of Communism in 1989 (Koráb, Hanzelková and Mihalisko, 2008). Family business is a specific model of company management and has many pros and cons. On the one hand, there is a larger community among members of families, and a large role is played by informal connections. On the other hand, family business activity can also have a very unpleasant effect on the functioning of a family under certain circumstances. If the business is participated in by a family as a whole, then in the event of failure and/or at a time when the company is not succeeding, the entire family truly suffers as a result.

Long-term research conducted by the Czech Association of Small and Medium-sized Enterprises has revealed that $15 \%$ of GDP can be attributed to family firms, which is due to the relatively short history of business activity in the Czech Republic. According to the research, $50 \%$ of customers consider these companies' products as high quality, and $46 \%$ say they are reliable. Customers are mostly motivated to make purchases from family firms by quality $(71 \%)$, the personal approach to the customer (54\%) and support for local production (49\%) (Probyznys, 2014). Sectors that are specific for family business activity are also interesting. According to a study carried out by the Equa Bank, the Czechs mostly buy groceries from family firms (87\%), followed by crafts (75\%), services (44\%) and clothing and shoes $(37 \%)$ (Equa Bank, 2014). Finally, it is necessary to define the term "family firm" clearly. The term "family firm" is perceived differently in different areas, and there is no exact common definition worldwide. For the purposes of this work, the characteristics of a family firm are as follows:

- At least two individuals directly participate in the management of a company, and these persons together or their families own at least a 50\% stake in the particular company.

- The company has a history of more than ten years.

- In the future, the company will belong to a close relative, which will preserve the ownership structure.

\section{Methodology}

At the beginning of the project, a conceptual framework was set up which defined the approach that the research team would use. This conceptual framework ensured that individual activities corresponded to each other, so that a logical correlation would be maintained; the concept is presented in figure 1. The first part of the concept, which contained a thorough investigation of research mainly from literary sources and scientific databases, 
served as an informational basis for the entire project. These secondary sources focused on the characteristics of the issue, which consisted of a study of the latest trends related to social media and the exact definition of family business. Primary studies corresponded to the research part, which were a combination of quantitative and qualitative methods. Both methods of research were applied in relation to each other. The qualitative research preceded the quantitative research. The qualitative part, which was realised with the help of interviews with various focus group members, had an exploratory purpose, which served for familiarisation with the issue from the point of view of social media users. The number of participants in each focus group was $7-11$ persons. The length of the interviews was roughly set according to the number of questions to an hour and a half. In order to collect data, a research team made up of five persons was put together. The results of the interviews conducted in this way were evaluated by a team made up of two experts in the field of social media, two persons employed in marketing and one psychologist. The results of the focus group interviews served for setting up a comprehensive questionnaire, which was subsequently distributed to respondents with experience with social media. From the information originating from the qualitative research, a questionnaire was set up, which served as a basis for the quantitative research. The questioning was based on direct or mediated contact between the researcher and each respondent. The electronic questioning method was used. The subject of the questions was social media, and therefore this subject was selected as a communication channel, which was complemented by questioning via email. An advantage of electronic questioning was the ability to focus on certain groups of respondents with relatively low costs. The survey consisted of 20 scaled questions that come from the previous focus group. The questions assessed the importance of individual attributes using a seven-point scale. 600 completed questionnaires were approved for the survey. Questionnaires that were incomplete or logically unsuitable were excluded. Respondents were grouped according to demographic characteristics - sex, age, education and economic activity. The survey was designed just for Czech respondents, the reason being the specific way in which Czechs approach social media.

Figure 1: Conceptual framework of this document

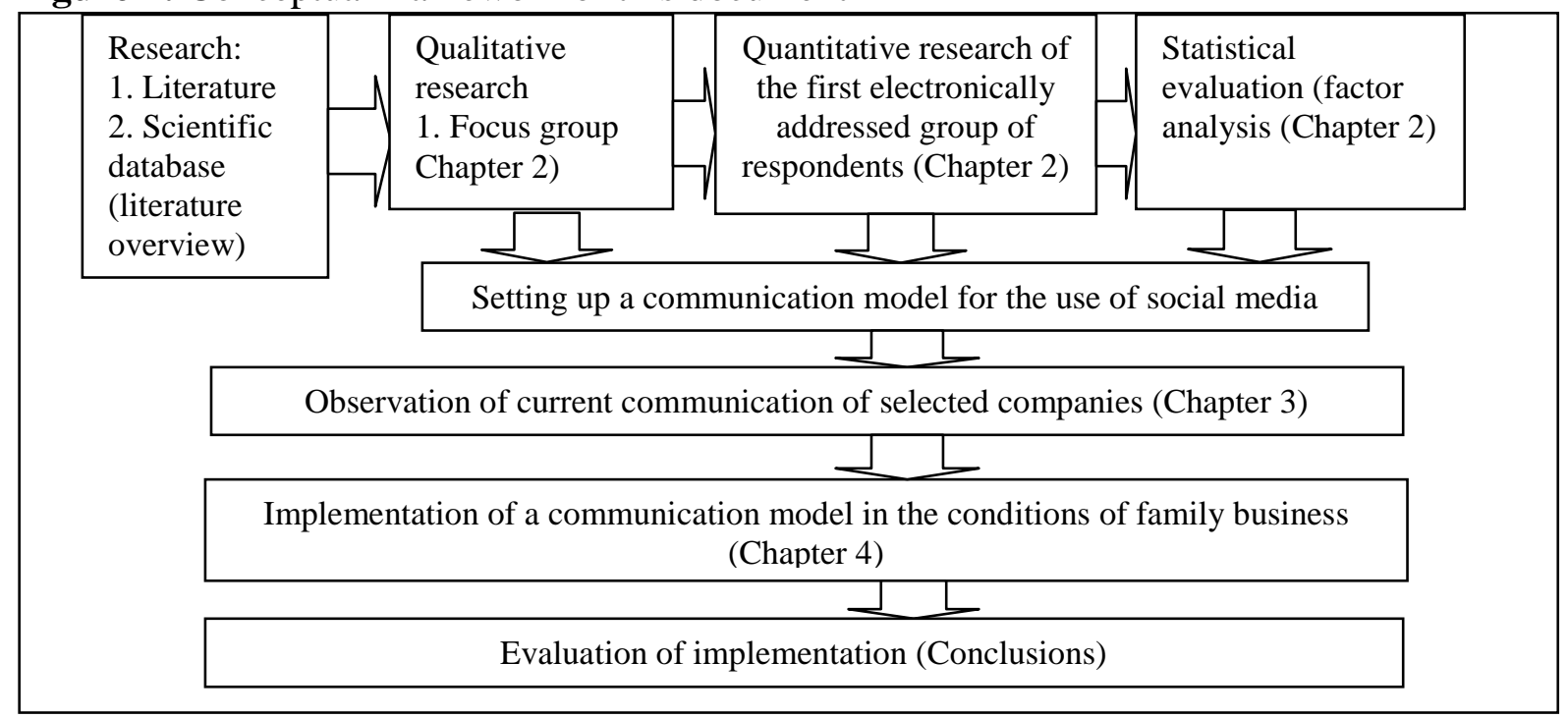

Source: authors' calculations.

Another step was a statistical evaluation, in which three types of variables were used: nominal, cardinal and ordinal. The main method is based on descriptive statistics, to which a greater dimensional factor analysis was linked, which focused on an analysis of the structure 
of the internal relationships between a large number of variables and use of the compilation of a smaller number of latent variables, known as factors (Churchill, 1987). During interpretation of the factors, the factor burden was examined, which was represented by a correlation coefficient between the original variable and the factor. Correlations greater than \pm 0.5 were considered significant. If any variables did not reach the specified values, they were excluded, and the analysis was carried out again, sometimes several more times, until the correlation coefficients of all variables reached the minimum value of \pm 0.5 . The purpose of this approach was to obtain an optimal number of variables. The obtained factors were named based on the composition of the variables (Meloun and Militký, 2006).

Setting up the communication model was the conclusive result of the first part of the project, lasting one year. Therefore, a model makes it possible to show objective reality in a simplified manner and to capture only the aspects of the particular phenomenon that are considered important, meaning those that are close to the purpose that the model is intended to fulfil. After setting up the communication model, qualitative research was conducted using a comparison method, which is one of the basic methods of collecting primary data. Twenty companies were always selected on each type of social media, and they were subjected to thorough observation. The beginning of the practical verification of the empirical research in the form of implementation of the communication model in practice involved setting up a suitable approach, which lasted one year. The approach to the implementation was set with six points, which are presented in figure 2 .

Figure 2: Implementation approach

\begin{tabular}{|c|}
\hline Implementation of the communication model in practice \\
\hline 1. Defining the reasons for entry to and the reasons for expanding of social media. \\
\hline 2. Determining the aims of marketing communication on social media. \\
\hline 3. Describing the current status of communication on social media before implementation. \\
\hline 4. Determining the target group based on sorting parameters. \\
\hline $\begin{array}{l}\text { 5. Setting up a specific implementation of the model (type of social media, communication tools, } \\
\text { content formation, social involvement). }\end{array}$ \\
\hline $\begin{array}{l}\text { 6. An overall evaluation of the success of implementation of the communication model whilst } \\
\text { fulfilling the marketing communication plan on social media. }\end{array}$ \\
\hline
\end{tabular}

Source: authors' calculations.

The evaluation of the implementation was the last part of the entire process and was taken part in by a group consisting of marketers with experience and academic workers involved in marketing. The evaluation was carried out in five independent parts. The first phase, during which the company prepares the presentation but is not yet actively promoting it, is called the latent phase. This is followed by the active communication phase, in which the company promotes its activities with the aim of acquiring a fan base. The third phase is the viral distribution phase, in which the company attempts to shift the initiative involving acquiring new fans to the existing fans of the presentation. In the fourth, saturation phase, the number of fans does not increase significantly, and this phase is optimal for communication with fans with the aim of transforming the communication with them through conversion. Once the presentation has fulfilled its purpose, there is an ongoing fifth phase, which in some cases can end by leaving the social network (Bednáŕ, 2011). 


\section{Research into current communication on social media}

The main aim was the implementation of social media in family business environments. The already presented model was used as the main way to apply social media successfully in practice. However, this model is only a simplified way of noting the process that can lead to success. In order for success in communication to be achieved, it was necessary to complete the model with a range of solution variants across all four points in the model. If there is a sufficiently large range of options, then it will be up to the company to decide which strategy or tactics to choose in communication. For fulfilment of the communication model through content, the "observation" method was used, which was applied to the most successful companies on social media. Communication tools in various modifications were examined. A research team was set up for evaluation, which consisted of three experts in marketing research. Such research was applied to companies which due to their characteristics belong to the category of family business. The evaluating parameters are presented in table 1 . The table presents six evaluating factors which originated from secondary research conducted by Ad age, in which 500 marketing experts in on-line communication participated. The was converted into percentage weight values, which served for determining which companies would be examined. These five attributes were monitored for the 20 most successful companies with the largest numbers of fans. The results of the observation were used for communication options of family companies.

Table 1: Evaluation of company communication

\begin{tabular}{|c|c|c|}
\hline Order & Evaluating point of view of communication on social media & Weight of individual variables \\
\hline 1. & Building brand awareness & $45 \%$ \\
\hline 2. & Increasing a website's visit rate & $20 \%$ \\
\hline 3. & Gaining fans and evaluators & $10 \%$ \\
\hline 4. & Regular contact with customers & $10 \%$ \\
\hline 5. & Forming business relationships & $10 \%$ \\
\hline 6. & Business relationships & $5 \%$ \\
\hline
\end{tabular}

Source: authors' calculations.

The first point in the model is selection of the type of social media. If social media are referred to as a communication tool usable for marketing, then it is necessary to divide social media correctly based on the application of marketing tactics. Marketing tactics can be defined as the ways companies fulfil their communication strategies. They can be divided as follows:

$>$ Social networks - Facebook, MySpace, LinkedIn, Google+

$>$ Blogs - own websites, public spaces

$>$ Micro blogs - Twitter

$>$ Discussion forums, QaA portals - public forums, Yahoo!, Answers

$>$ Wikis - Wikipedia, Google Knol

$>$ Social bookmarking systems - Digg, Delicious, Jagg

$>$ Shared multimedia - YouTube, Instagram

For each type of social media, there are basic variants most commonly used in the EU.

Another part of the communication model was the selection of communication tools for setting up a corresponding communication mix:

Social networks - Advertising, Sales support, Public relations, Direct marketing, Viral marketing, Guerrilla marketing, Mobile marketing, Buzz marketing

Blogs - Advertising, Sales support, Public relations, Direct marketing, Engagement marketing, Mobile marketing, Astroturfing 
Micro blogs - Advertising, Sales support, Public relations, Direct marketing, Engagement marketing, Mobile marketing, Astroturfing

Discussion forums, QaA portals - Advertising, Public relations, Direct marketing, Astroturfing

$>$ Wikis - Public relations, Mobile marketing

Social bookmarking systems - Advertising, Public relations, Mobile marketing, Buzz marketing

Shared multimedia - Advertising, Public relations, Viral marketing, Engagement marketing, Product placement, Mobile marketing.

It is apparent from the results that a different communication mix is used for each type of social media. The summary of these communication tools was added to the descriptions of the more detailed characteristics of individual marketing communication methods.

The third point in the model, corresponding to setting up a communication mix, is content creation. Each communication mix tool has its own specific form of tactics on social media. These tactics change relatively quickly over time, and the situation that research has identified may change in just one year. This point needs to be subjected to regular updating.

The results of the observation are presented in the following points:

$>$ Advertising - advertising banner, pop-up, catalogue, sector portal, context ad (link).

$>$ Sales support - discounts, samples, coupons, contests and surveys.

$>$ Public relations - company blogs, press releases, conferences, sponsoring.

$>$ Direct marketing - newsletter, chat, social communication, forums.

$>$ Guerrilla marketing - provocative, controversial, erotic, humorous and/or aggressive means of conveying information.

$>$ Buzz marketing - whipping up excitement about a product through non-conventional, shocking, sexy or humorous marketing methods. Users can talk about products themselves without the company's involvement.

$>$ Viral marketing - funny and interesting messages (photos, videos, text) are spread through a network via users forwarding them to others.

$>$ Product placement - Products or services are intentionally placed in films, music clips and/or video games.

$>$ Mobile marketing - use of display on mobile devices, such as mobile phones and iPads.

$>$ Engagement marketing - companies engage customers in the creation of offers, product appearances and proposing sales methods. The customer is pulled into the game and becomes an active builder of the brand.

$>$ Astroturfing - companies use paid positive reactions from consumers or fans to promote their brands. These are fictitious positive and/or negative reactions.

The result was 11 types of marketing communication tools which companies apply in practice. This interconnection forms the basic attributes for subsequent implementation of the tactics in practice. The fourth part of the communication model is social engagement. It is an enhancement added to a message, which respondents in all examined groups consider to be very serious. Social engagement affects customers, but they must find out about it. The social media area is an ideal platform for informing customers. The most important areas of social engagement for respondents are: environmental protection, ethics and support for sport.

\section{Implementation of social media in practice}

The main aim of the project presented in this document was to identify options for using social media in marketing communication with consumers in family firm environments. The results of the project could subsequently serve family firms as a guide or as assistance in the 
practical involvement of social media in communication with customers. For the implementation of social media in practice, a communication model was used which was the subject of previous research by the author and presented in a periodical with an impact factor (Myslivcová and Ungerman, 2014). This model is primarily designed for small and mediumsized enterprises, among which fall the family businesses with which cooperation was established. The contribution confirms the possibility of using this model in practice especially for family businesses. The communication is however merely a simplified rendering of the process. Its specific fulfilment of the communication strategy and tactics suitable for family businesses is the only basic difference from general utilization of the model. The model is thus designed for all companies, but the contents presented in Chapter 3 are specifically for family businesses. This implementation of social media was carried out in cooperation with three family companies in order to ensure objectivity. In order to ensure the required extent, only yearly cooperation with one company is presented.

\subsection{Presentation of the family firm}

In order to protect the cooperating company from competition, its name and the names of its owners were changed herein. Company X was established in 1995 by Mr and Mrs Novák, and since its founding it has been involved in the industrial production of a specific product intended for construction. Company $\mathrm{X}$, through its characteristics, fulfils the pre-defined parameters for a family firm. In terms of size, it is a small company which employs 30 people. It is a prospering company which has a stable position on the Czech market. It uses special technology to manufacture a specific product, which it sells on the industrial market. The customers of Company $\mathrm{X}$ are both domestic and foreign. Since deliveries have stabilised in the recent period and Company $\mathrm{X}$ possesses available production capacity, the owner has decided to apply a growth strategy. The company's marketing communication is not very extensive, and therefore the owners of the company have decided to establish cooperation with the author in order to engage in communication via social media.

\section{Reasons for entering social media}

The main reason why the prospering company decided to enter a new communication channel, social media, was that there were major opportunities on the market. These opportunities were related to the significant growth in demand for products on the B2C consumer market, which was based on new technology in the construction sector and reduction of the prices of offered products. Until then, the company was involved only on the $\mathrm{B} 2 \mathrm{~B}$ industrial market. Company $\mathrm{X}$ decided to react to the opportunities by addressing individuals and smaller construction companies.

\section{Defining the objectives}

Defining the objectives corresponded to the reasons that led to the company's entry into social media. The main aim was to acquire new customers from the consumer market. This main aim is broken down in detail below and consists of the following objectives:

- to acquire 500 active fans on social media within three months;

- to get 30 new fans each subsequent month;

- to get 50 new comments from fans per week;

- to consistently maintain $5 \%$ of active fans from the total number of fans on social media;

- based on the conversion to social media, negotiations with a new client regarding an order should occur at least once per month;

- 1,000 people should be persuaded to view company presentations on shared multimedia;

- information should be provided intensively about products on the consumer market; 
- construction companies which could use the product sold by Company $\mathrm{X}$ should be contacted.

\section{Initial status of marketing communication}

The marketing communication of Company $\mathrm{X}$ at the time of cooperation did not include any activities on social media. The communication of Company $\mathrm{X}$ was primarily focused on the B2B market, and its communication mix was based on that focus and involved personal sales and direct marketing. It can be stated in general that the communication of Company $\mathrm{X}$ was very limited and focused only on forming business relationships with existing customers. Efforts to acquire new customers were minimal.

\section{Determination of the target group}

Determination of the target group was based on the aims that led Company X to get involved in social media. The target group was determined with consideration for the specific uses of the offered product in the construction sector. The offered product is of very high quality, but is relatively expensive and is used during the construction of family houses. This was the basic premise during the definition of the target group, which consisted of the sorting parameters of age, education and economic activity. The target segment consists of people over the age of 30 who have a regular income and belong to the upper middle class. Education is also related, given that the product, due to its specific characteristics, would tend to impress groups of customers with higher professional or university education more. In terms of economic activity, the product is clearly intended for economically active persons.

\subsection{Strategic communication solution}

A strategic phase corresponded to the preparation phase, and this strategic phase already included a practical solution. Cooperation began in June 2013, and its duration was agreed upon for a period of one year. The reason for the involvement mainly of social media was the willingness to invest only relatively limited financial means into the communication campaign, and social media are cheaper in this respect than traditional media. The strategic proposal is presented in figure 3. 
Figure 3: Communication model of family business $X$

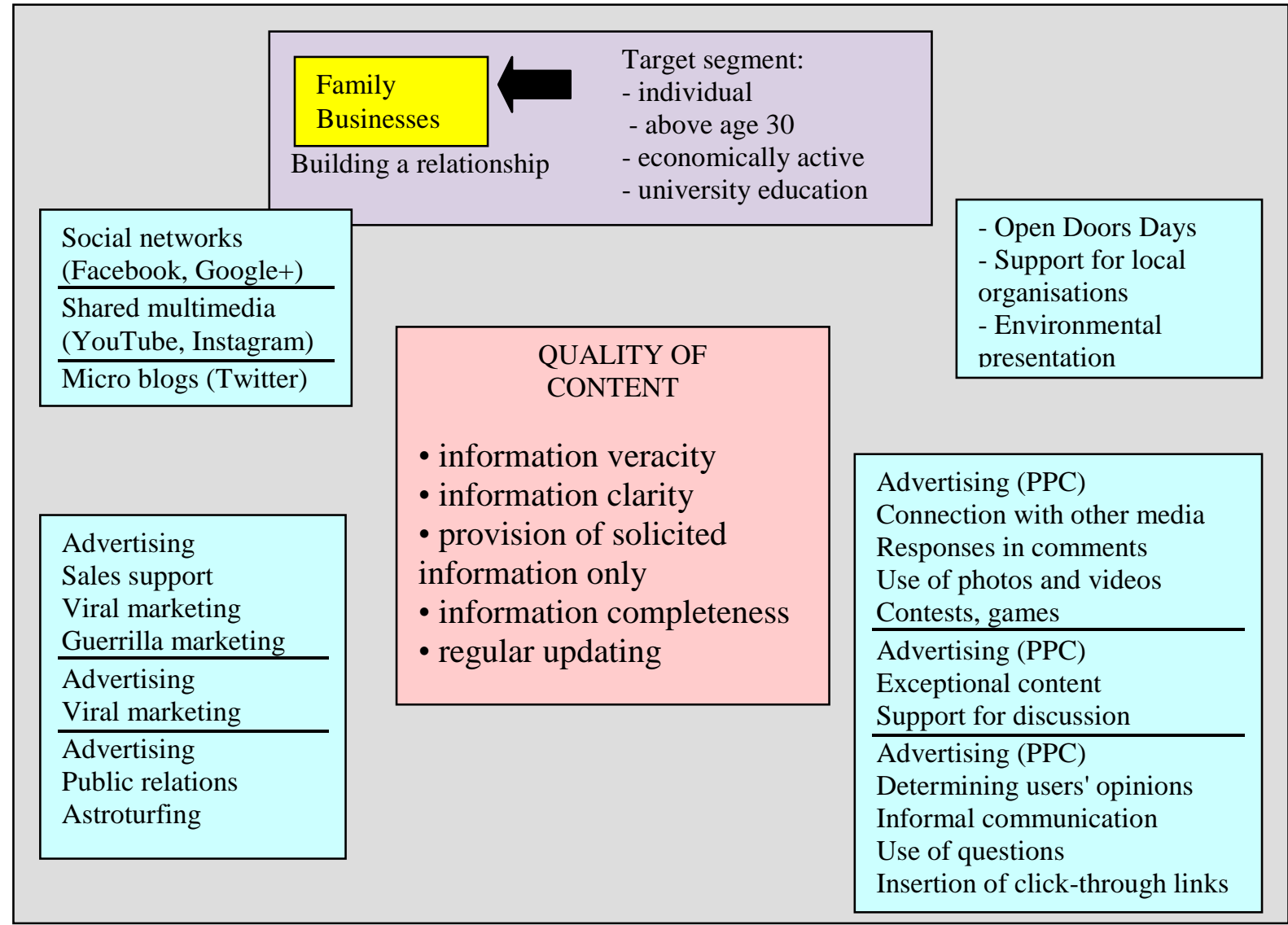

Source: authors' calculations.

The first point of implementation of social media was clearly defining the target segment. The model includes an exact specification of the target group, which consists of individuals over the age of 30 who are economically active and have a university education. Company $\mathrm{X}$ intended to establish a long-term relationship with this target group.

The selection of social media as the second point of the communication model was relatively far-reaching and courageous, considering the fact that Company $X$ did not have any experience with such means of communication. Company $\mathrm{X}$ proposed implementing three types of social media into the communication. From the range of social networks, the first choice was clearly Facebook, which is currently the most widely used social network in Central Europe. The second choice was the continuously developing social network Google+. The reason for choosing two social networks was that if content was created for one platform, it could be mirrored for another social network in the same style. Of the shared multimedia platforms, again, two were chosen. The first choice was clear. YouTube was selected for videos. This choice was a logical tool enabling the presentation of products during the construction of family houses. The second chosen multimedia platform was Instagram, which serves for the presentation of photos of already fulfilled orders. The reason for the company's decision to present photos was again to familiarise users with the options for use of the product in the construction sector. The final choice was a micro blogging platform. Due to its popularity, Twitter was the only possible selection. The reason was the need to familiarise users with the company and its product. The aim was to prompt discussion about topics related to the construction of family houses, in which the offered product could be used. 
Setting up the communication mix was the content of the third point of the model. For the social networks Facebook and Google+ the communication mix was identical, and contained advertising, sales support, viral marketing and guerrilla marketing. The representative of Company $\mathrm{X}$ decided to promote mainly advertising focused on an exactly defined market. A major effort by Company $\mathrm{X}$ was also devoted to attracting the public's attention via guerrilla marketing, which was subsequently spread virally via social media. For both YouTube and Instagram an identical communication mix was also set up, since they each involved a somewhat different presentation method. The communication mix contained advertising, public relations and viral marketing. For shared multimedia as well, greater emphasis was placed on paid advertising for an exactly defined group of potential clients. Advertising was viewable always at the beginning when the presentation was started by people from the target group. The targeted advertisement was added in an effort to spread videos and photos virally. The communication mix for Twitter consisted of three tools: advertising, public relations and astroturfing. The use of targeted advertising again created a basis for communication on Twitter. Company X even resorted to a controversial tool, astroturfing, based on which it commented on individual contributions, but pretended that the comments had been added by users.

The fourth part of the communication model is content creation, which is based on the exact specification of the method of fulfilling the communication strategy. This fulfilment method can also be referred to as a tactical one, and it is necessary to re-evaluate such tactics regularly, which Company $\mathrm{X}$ has done every month. The model specifies only original processing for the start of the communication. It is followed by a brief analysis of tactics to get an impression of how the method of fulfilling the communication mix looked. Specific tactics correspond to individual types of social media:

- Facebook, Google+ (PPC advertising, links with other media, responses to comments, using photos and videos, contests, games).

- YouTube, Instagram (PPC advertising, exceptional contents).

- Twitter (PPC advertising, determining users' opinions, informal communication, using questions, supporting discussion, inserting click-through links).

The biggest opportunities for acquiring new customers from the consumer market were focused on PPC advertising, in relation to which payments are made simply as a result of users opening links. This targeted communication mix led to an increase in expenses. Besides advertising, the tactics were based on a variety of content which would be connected across all types of social media. A time schedule was also part of this point in the communication model. It can generally be stated that each communication mix was synchronised in time, and that the implementation occurred based on the marketing employee's capabilities.

The final part of the communication model is social engagement. Although this involves communication via social media, social engagement occurs in real life and only subsequently occurs on social media. The social engagement proposal involved three activities: an Open Doors Day, support for a local organisation and an environmental presentation of the company's business. The Open Doors Day was a one-off event tied to a cultural programme, with a presentation of the company's own products. It was presented on social media a month before it started. During this event and after it ended, information about it was presented extensively on social media. Subsequently, all records and comments were presented in the form of text, photos and videos on all of the social media platforms that Company $\mathrm{X}$ had chosen. The local organisation that Company $\mathrm{X}$ chose to support was the local fire brigade, which is highly appreciated by the public and is appropriate for presentation on social media. Since Company $\mathrm{X}$ pays very close attention to adhering to environmental principles, in order 
to fulfil this part of the communication strategy, it only needed to present its activities in a free form on social media.

\section{Conclusions}

The final evaluation of the implementation of social media was carried out by the company's owner and an independent group consisting of a marketer with experience and two academic workers involved in business marketing. The evaluation had two parts. The first involved evaluation of the qualitative points of view in connection with the building of relationships with consumers. The second part evaluated the quantitative indicators based on data from Facebook Insights, which provides statistics about Facebook related to fans, their likes and the reach of published contributions, as well as about page visit rate and users' involvement. For the statistical evaluation of data from Google+, the Google Analytics tool was used, which can calculate the value of social networks and measures sales, conversions and visitors' interactions with content published on the web and on social networks. A crucial factor in view of the set objectives was data concerning to what extent people coming from social networks become real customers. This information was monitored with the help of discount codes published only on social networks together with asking new customers how they had become aware of the company.

The independent team evaluation from a time scheduling point of view on social media goes through five phases. The evaluation was presented in individual phases:

- Latent phase - this included the preparation of presentations on social media, which were conceived as an independent project. This phase was prepared with a limited time schedule. In the latent phase, initial messages presented only for social networks were put together. The company first focused on preparation of the contents of advertising, which was provided by a specialised agency. Other activities were ensured by the company's own employees shortly before the campaign was started. The company prepared instructional videos and photos of successful projects and prepared contests and a lot of information based on scenarios for the gradual promotion of discussions. The evaluation of the preparatory phase revealed absolute satisfaction, which was due to the sufficient amount of time, the involvement of professionally educated people and enough financial means.

- Active communication phase - as soon as the presentation had been prepared, filled with content and had an acceptable form, it was launched. The strategy included three types of social media, and initially the company focused only on social networks, where it attempted to gain a fan base with the help of the administrator's friends and subsequent viral promotion. The effort to underestimate in communication led to a relatively significant amount of "liking". Paid advertising enabled the company to put out clear messages with graphic content to a pre-defined segment. Over time, with the help of barter cooperation, it became possible to connect links with the presentations of cooperating companies. It also became possible to promote like boxes for all used social media on the first page of the web presentation. After a month, the company succeeded in filling all of the planned types of social media with content. This phase lasted approximately a month, and during that month contact was established with approximately 500 fans on all types of media. The activities on both social networks were evaluated positively, but the situation when addressing fans on shared multimedia platforms and Twitter was worse. Overall, this phase appeared successful, since all planned activities had been fulfilled, and fans' participation corresponded to this.

- Viral marketing phase - In this phase, the main goal was to support fans by encouraging the most activity and initiatives to expand the base of fans and for the institutionalised spread of information to be replaced by viral marketing. This step was very successful, since its key is quality content of the presentation and interaction with fans, and the company achieved these 
goals. The basis for success was regular updating and interesting contents, which users viewed as very interesting. Interactions gradually grew in the group, to which Company $\mathrm{X}$ managed to respond adequately. According to the plan, this phase was supposed to last approximately four months, but the company managed to fulfil it after three months. The evaluation of this phase was positive, since two-way communication was established, along with retaining of users' interest for the entire three-month period.

- Saturation phase - in this phase, the target number of users had already been achieved, which subsequently grew very slowly. This phase was conditioned on huge success in the previous phase. The impact on the target group was significant and directly led to an increase in demand for the product. Successful communication contributed to growth in the company's turnover. The evaluation of this part was positive, even though it cannot be determined exactly what share of the turnover increase could be attributed to communication on social medial.

- Ongoing phase - in the previous phase, a culmination of the effects of communication was achieved, and therefore the presentation on social media fulfilled its purpose. It was necessary to continue the path of this success so that the tendency of fans' involvement would not decline. Thanks to regular re-evaluation of communication tactics and a constant innovative approach, this phase was a success, and the number of the company's fans grew slightly on all types of social media.

On behalf of Company $\mathrm{X}$, the cooperation on social media was evaluated directly by the company's owner, who was clearly satisfied with its entry into social medial. The owner wants to continue participating in social media even after the cooperation ends, and he has set goals for an increase in activities in the future. The greatest satisfaction was expressed with the universality of the model. The following principles were strictly adhered to, which are described in the middle of the model and which led to successful communication: truthfulness of information, comprehensibility of information, only requested information, complete information, regular updating. Social media resulted in increased demand, addressing a new market and building better relationships with customers. The following conclusions emerge from the final comparison of the results achieved and the exact goals that were set: 3,250 fans in total were gained on the social networks Facebook and Google plus, instructional and event videos were viewed by 11,460 people, and its Twitter micro blog has 1,120 followers. About $6 \%$ of the fans are active and provide regular feedback. On the B2B market it managed to establish contact via social media with 55 construction companies. The aim of this entire project was through the aid of social media and implementation of the latest marketing approaches to help family businesses and thereby support sustainable development mainly in small towns and municipalities. This objective was successfully fulfilled, and this document can serve as a guide for other family businesses. During the final summarising, the team of evaluators agreed on the huge success of implementing practical use of social media. Not only was cooperation with Company $\mathrm{X}$ evaluated well, but cooperation with two other family firms was, too, and although they had selected a different strategic and tactics, their success was comparable. Company $\mathrm{X}$, following a year of cooperation on the use of social media, successfully entered the consumer market and was helped in doing so by communication on social media. Although the financial benefits of implementing communication via social media cannot be identified exactly, the proportion of costs and revenues clearly generated profit. The team also positively evaluated the social impact of involvement in social media. The owners reacted to the increase in demand and Company X's entry into a new market by increasing the number of employees, which is having a positive effect on the region. This project highlights the importance of family businesses and their positive effect on economic sustainability. 


\section{References}

[1] AD AGE, 2012. Ad Age Survey: Marketers Buy Facebook More for Awareness Than Likes or Leads [online]. [Accessed 6th September 2014]. Available at: http: //adage.com/article/digital/survey-marketers-s-top-goal-facebook-adsawareness/2358

[2] BEDNÁŘ, V., 2011. Marketing na sociálních sitích. 1. vyd. Brno: Computer press. ISBN 978-80-251-3320-0.

[3] BLAŽKOVÁ, K. and J. DĚDKOVÁ, 2014. The Competitive Environment Among Companies in the Czech Part of Euroregion Neisse-Nisa-Nysa. E+M Ekonomie a management, XVII(3), 86-99. Liberec: Technická univerzita Liberec. ISSN 1212-3609.

[4] ČERVENKOVÁ, E., P. ŠIMEK and M. STOCES, 2011. Social Networks as an Integration Tool in Rural Areas - Agricultural Enterprises of the Czech Republic. AGRIS On-line Papers in Economics and Informatics, 3(1), 53-60. ISSN 1804-1930.

[5] CRAINER, S., 2000. Moderní management: základní myšlenkové směry. 1 vyd. Praha: Management Press. ISBN 978-80-7261-019-8.

[6] CONVERSOCIAL, 2013. Social Customer Service Performance Report [online]. [Accessed 29th January 2015]. Available at: cdn2.hubspot.net/hub/154001/file214612143pdf/Social_Customer_Service_Performance _Report_June 2013.pdf

[7] DUNDA, V., 2011. Sociálne siete-dobrý sluha / zlý pán [online]. [Accessed 10th November 2013]. Available at: http://www.itnews.sk/tituly/infoware/2011-0817/c140822socialne-siete-do

[8] EQUA BANK, 2014. Češi chtějí nakupovat u rodinných firem, jsou ochotni si i připlatit. [online]. [Accessed 12th May 2013]. Available at: www.equabank.cz/o-nas/tiskovezpravy/cesi-chteji-nakupovat-u-rodinnych-firem-jsou-ochotni-si-i-priplatit-274/

[9] FEDORKO, R. and R. BACÍK, 2013, Sociálna siet facebook ako marketingový nástroj podpory zákazníkov. Mladá Veda, 2, 88-91. ISSN 1339-3189.

[10] CHURCHILL, G. A., 1987. Marketing Research: Methodological Foundations. 4th ed. Chicago: Dryden. ISBN 0-03-005532-6.

[11] HEILIGMAN, M. and H. LIEU, 2012. What's A Company Like You Doing In A Social Place Like This? [online]. [Accessed 15th March 2014]. Available at: http: //www.forbes.com/sites/sap/2012/10/17/whats-a-company-like-you-doing-in-a-socialplace-like-this/

[12] HNÁTEK, M. and M. HNÁTKOVÁ, 2014. Family business in the light of the corpus and the Czech law. Acta academica karviniensia, 14(3), 49-58. ISSN 1212-415X.

[13] HOMOLKOVÁ, V. and M. TALIÁNOVÁ, 2012. The risk of impact on line social networks on students lifestyle. Aktuálni Otázky Sociální Politiky, 6, 128-134. ISSN 18049095.

[14] JANOUCH, V., 2011. Internetový marketing. Prosad'te se na webu a sociálních sítích. Brno: Computer Press. ISBN 978-80-251-3269-2.

[15] KALOUDA, F., V. KORÁB, R. SSALQUEIRO and M. SANCHEZ-APELLANIS GARCÍA, 1998. Jak pracují malé rodinné firmy. 1. vyd. Brno: PC-DIR. ISBN 978-80214-1121-8. 
[16] KOTLER, P., 2003. Marketing od A do Z. 1st edition. Prague: Management Press. ISBN 80-7261-082-1.

[17] KORÁB, V., A. HANZELKOVÁ and M. MIHALISKO, 2008. Rodinné podnikání. 1. vyd. Praha: Computer Press. ISBN 80-7204-454- 0.

[18] MARKOVÁ, S. and T. PETKOVSKÁ, 2013. Social media and supply chain. Amfiteatru Economic, 15(33), 89-102. ISSN 1582-9146.

[19] MELOUN, M. and M. MILITKÝ, 2006. Kompendium statistického zpracování dat: metody a řešené úlohy. 2. vyd. Praha: Academia. ISBN 80-200-1396-2.

[20] MC NAUGHTON, M., 2012. 40\% of UK Consumers Say Social Media Improves Customer Service [online]. [Accessed 10th May 2014]. Available at: http: //therealtimereport.com/2012/06/14/40-of-uk-consumers-say-socialimprovescustomerservice/

[21] MYSLIVCOVÁ, S. and O. UNGERMAN, 2014. Model of Communication Usable for Small and Medium-Sized Companies for the Consumer Communication in Social Media. E+ M Ekonomie a Management, XVII(1), 167-184. ISSN 1212-3609.

[22] PROBYZNYS, 2014. Češi chtějí nakupovat u rodinných firem, jsou ochotni si i připlatit [online]. [Accessed 10th January 2014]. Available at: http://probyznysinfo.ihned.cz/c162997850-cesi-chteji-nakupovat-u-rodinnych-firem-jsou-ochotni-si-i-priplatit

[23] TREADAWAY, CH. and M. SMITH, 2011. Marketing na Facebooku. Brno: Computer Press. ISBN 978-80-251-3337-8. 